\begin{tabular}{l} 
2. To: (Receiving Organization) \\
Distribution \\
\hline 5. Proj./Prog./Dept./Div.: \\
SNE Project/W- 441 \\
\hline 8. Originator Remarks: \\
For approval and release.
\end{tabular}

11. Receiver Remarks:

3. From: (Originating Organization)
Technical Integration
$\begin{aligned} & \text { 6. Design Authority/Design Agent/Cog. Engr.: } \\ & \text { C. C. Pitkoff }\end{aligned}$

C. C. Pitkoff

\author{
4. Related EDT No:: \\ NA \\ 7. Purchase Order No:: \\ NA \\ 9. Equip./Component No.: \\ NA \\ 10. System/Bidg./Facility: \\ CVDF/ $142 \mathrm{~K}$ \\ 12. Major Assm. Dwg. No.: \\ NA \\ 13. Permit/Permit Application No. \\ NA \\ 14. Required Response Date:
}

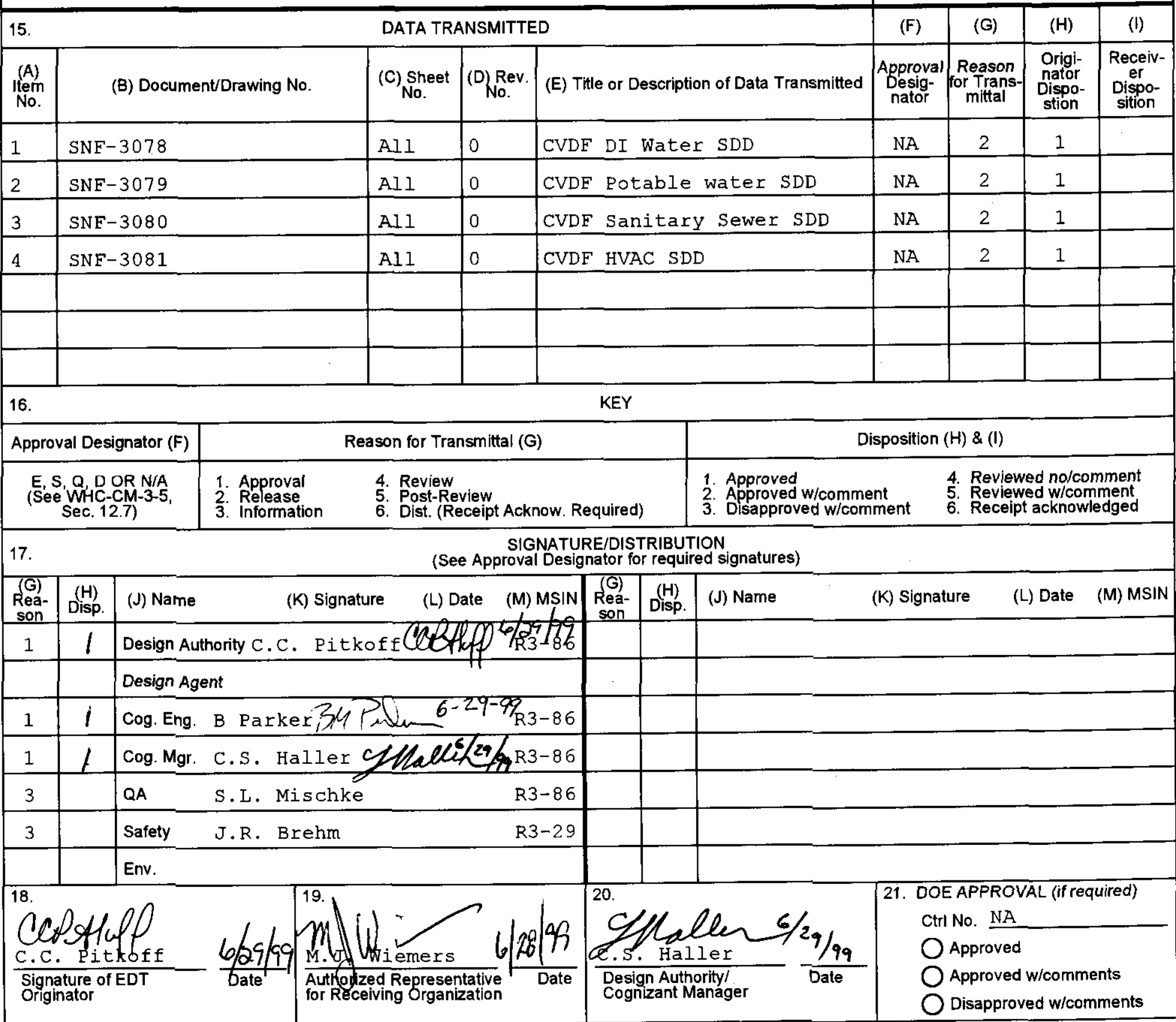




\section{Cold Vacuum Drying Facility Deionized Water System Design Description}

C. C. Pitkoff

DE\&S Hanford, Richland, WA 99352

U.S. Department of Energy Contract DE-AC06-96RL13200

EDT/ECN: 626308 (JKB 6130199$)$

Org Code: $2 \mathrm{~F} 800$

$\mathrm{UC}: 510$

B\&R Code: $39 \mathrm{EW} 70400$

CACN: 105568

COA: $\mathrm{A} 000$

Total Pages: 42 (JKB 6/30/49)

Key Words: SNF, CVD, W-441, design description, deionized water

Abstract: This document describes the Cold Vacuum Drying Facility (CVDF) de-ionized water system. The de-ionized water system is used to provide clean, conditioned water, free from contaminants, chlorides and iron for the CVD Facility. Potable water is supplied to the deionized water system, isolated by a backflow prevention device. After the de-ionization process is complete, via a packaged de-ionization unit, de-ionized water is supplied to the process deionization unit.

TRADEMARK DISCLAIMER. Reference herein to any specific commercial product, process, or service by trade name, trademark, manufacturer, or otherwise, does not necessarily constitute or imply its endorsement, recommendation, or favoring by the United States Government or any agency thereof or its contractors or subcontractors.

Printed in the United States of America. To obtain copies of this document, contact: Document Control Services, P. O. Box 950. Mailstop H6-08. Richland WA 99352. Phone (509)
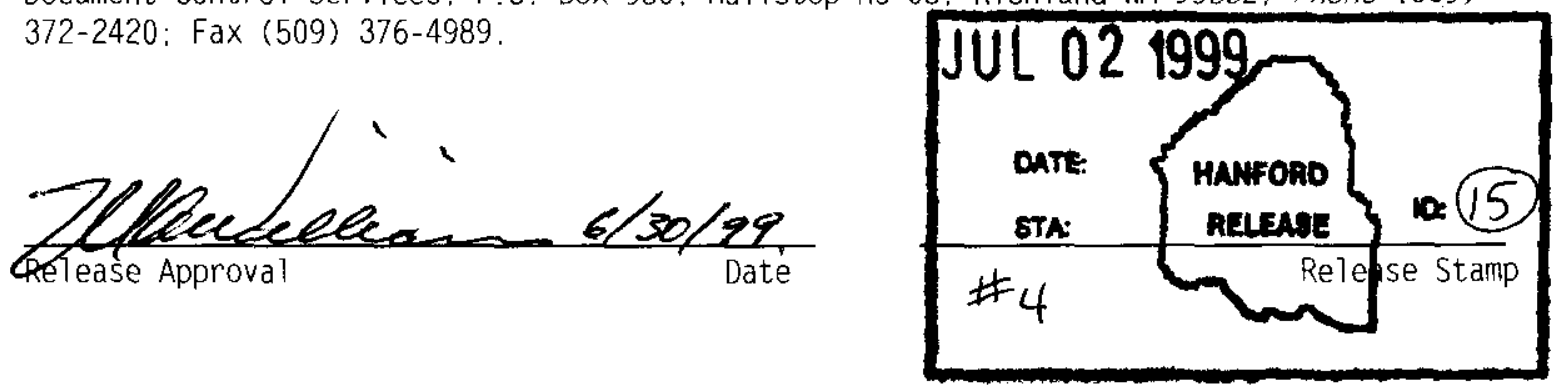

\section{Approved for Public Release}


SNF-3078 Rev 0

\section{COLD VACUUM DRYING FACILITY DE-IONIZED WATER SYSTEM DESIGN DESCRIPTION}

SYSTEM 25 


\section{TABLE OF CONTENTS}

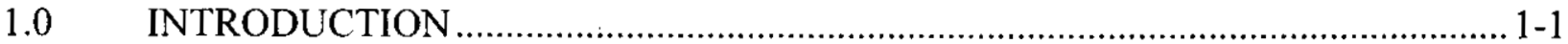

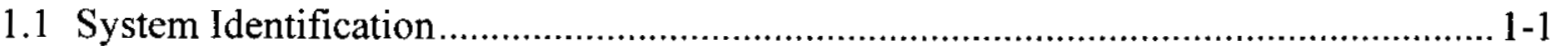

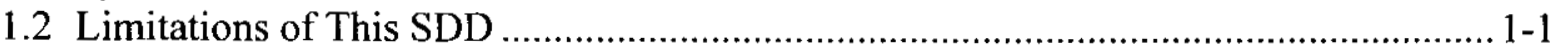

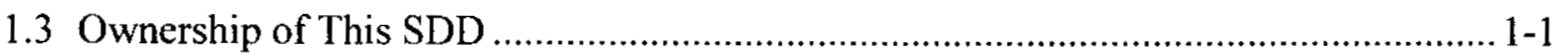

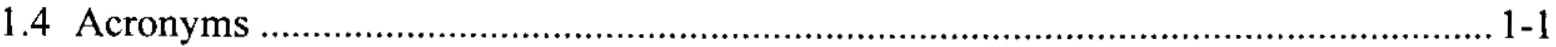

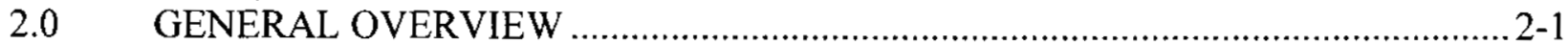

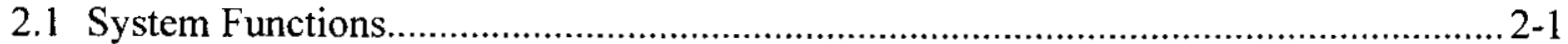

2.1.1 Normal Process Functions ……................................................................. 2-1

2.1.2 Safety Functions........................................................................................ 2-1

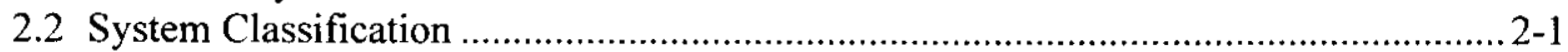

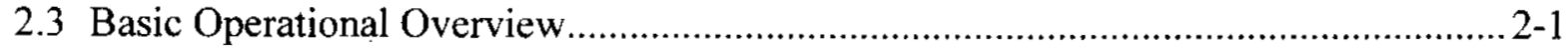

2.3.1 Basic Design Overview........................................................................... 2-1

2.3.2 Basic Operational Overview ........................................................................... 2-3

3.0 REQUIREMENTS AND BASES ……..........................................................

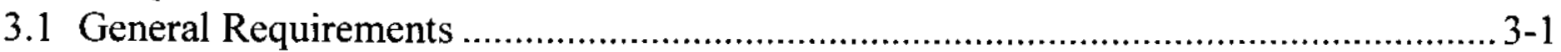

3.1.1 System Functional Requirements ............................................................. 3-1

3.1.2 Subsystem and Major Components ............................................................. 3-2

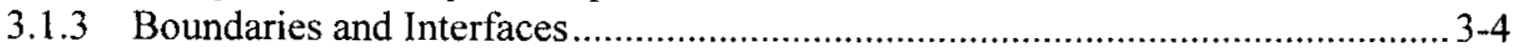

3.1.4 Codes, Standards, and Regulations ............................................................. 3-4

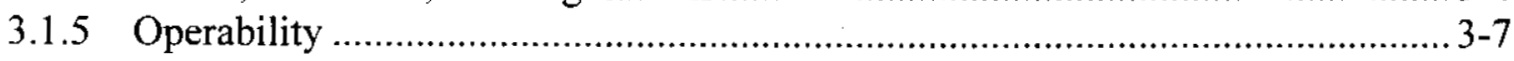

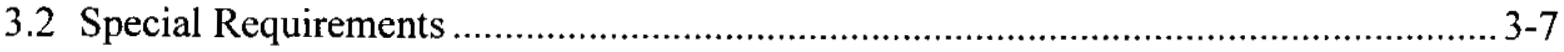

3.2.1 Radiation and Other Hazards .................................................................. 3-7

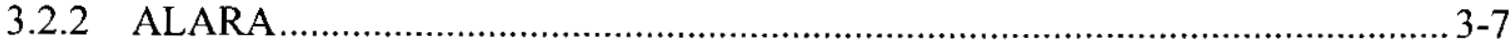

3.2.3 Nuclear Criticality Safety ....................................................................... 3-7

3.2.4 Industrial Hazards ................................................................................... 3-8

3.2.5 Operating Environment and Natural Phenomena ....................................... 3-8

3.2.6 Human Interface Requirements .............................................................. 3-8

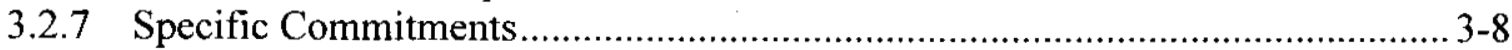

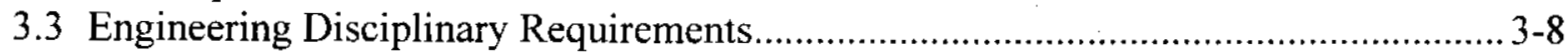

3.3.1 Civil and Structural .................................................................................... 3-8

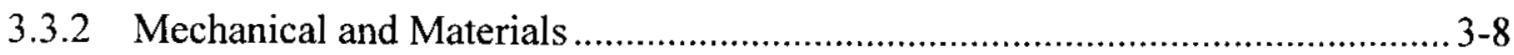

3.3.3 Chemical and Process ................................................................................ 3-9

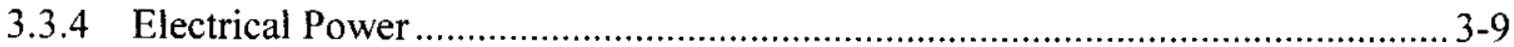

3.3.5 Instrumentation and Control ...................................................................... 3-9

3.3.6 Computer Hardware and Software............................................................... 3-9

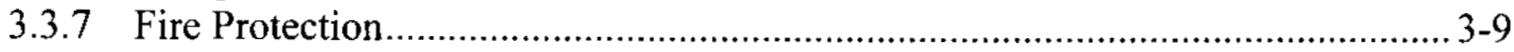

3.4 Testing And Maintenance Requirements ............................................................. 3-9

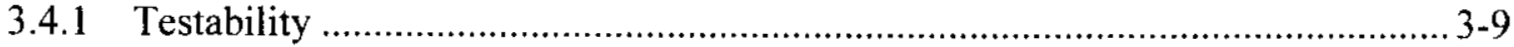

3.4.2 Technical Safety Requirement (TSR)-Required Surveillances .......................... 3-9

3.4.3 Non-TSR Inspections and Testing ………................................................. 3-9

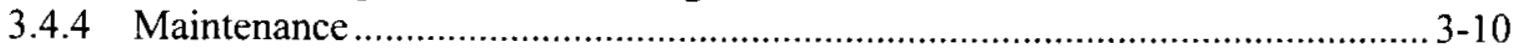

3.5 Other Requirements..................................................................................... 3-10

3.5.1 Security and Special Nuclear Material (SNM) Protection................................. 3-10 
3.5.2 Special Installation Requirements.............................................................. 3-10

3.5.3 Reliability, Availability, and Preferred Failure Modes....................................... 3-10

3.5.4 Quality Assurance ............................................................................... 3-10

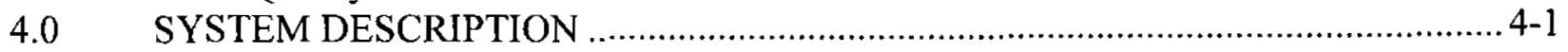

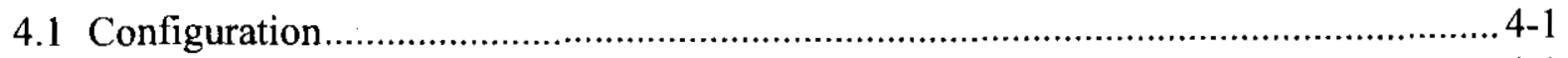

4.1.1 Description of System, Subsystems, and Major Components ............................. 4-1

4.1.2 Boundaries and Interfaces............................................................................. 4-9

4.1.3 Physical Location and Layout......................................................................... 4-9

4.1.4 Principles of Operation ......................................................................... 4-10

4.1.5 System Reliability ............................................................................... 4-10

4.1.6 System Control Features .............................................................................. 4-10

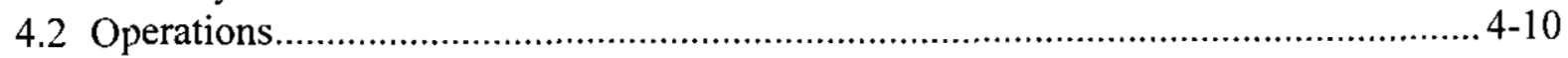

4.2.1 Initial Configurations (Pre-startup) .............................................................. 4-11

4.2.2 System Startup ................................................................................. 4-11

4.2.3 Normal Operations................................................................................. 4-11

4.2.4 Off-Normal Operations ........................................................................... 4-11

4.2.5 System Shutdown ..................................................................................... 4-11

4.2.6 Safety Management Programs and Administrative Controls............................. 4-11

4.3 Testing And Maintenance ................................................................................... 4-11

4.3.1 Temporary Configurations...................................................................... 4-12

4.3.2 TSR-Required Surveillances.................................................................. 4-12

4.3.3 Non-TSR Inspections, and Testing ......................................................... 4-12

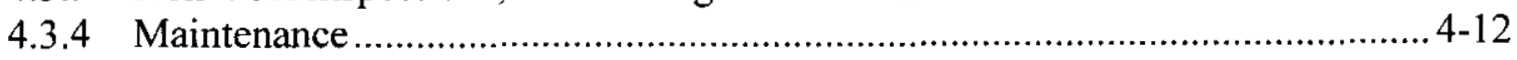

4.3.5 Equipment Calibration .............................................................................. 4-12

\section{APPENDICES}

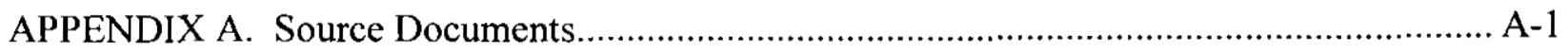

APPENDIX B. System Drawings ..................................................................................

APPENDIX C. System Procedures................................................................................... 
SNF-3078 Rev 0

\section{LIST OF FIGURES}

Figure 2-1. General Layout of De-ionized Water System ................................................... 2-2

Figure 4-1. De-ionized Units and Distribution .................................................................... 4-2

Figure 4-2. PWC System/De-ionized Water System Interface .................................................. 4-5

Figure 4-3. De-ionized Water Flush to MCO …………….................................................. 4-6

Figure 4-4. Tempered Water System Interface ...................................................................... 4-7

Figure 4-5. DE/HE Interface ....................................................................................... 4- 


\subsection{INTRODUCTION}

\subsection{System Identification}

This system design description (SDD) addresses the de-ionized water for the Cold Vacuum Drying (CVD) Facility. The discussion that follows is limited to the supplying of water through the CVD Facility for process use, as shown on drawing H-1-82222, Sheet 1 of 2, CVD Facility Mechanical Utilities Water and Compressed Gases $P \& I D$.

This SDD, when used in conjunction with the other elements of the definitive design package, provides a complete picture of the de-ionized water system for the CVD Facility. Elements of this SDD include functions, requirements, and descriptions. Other documents comprising the definitive design of the system include:

- $\quad$ Project design requirements (HNF-SD-SNF-DRD-002)

- $\quad$ Master equipment list (SNF- 4148)

- Data and calculation matrix tracking list (SNF-3001)

- $\quad$ Sequence of operations (see HNF-2356).

\subsection{Limitations of This SDD}

This SDD has been prepared with best available information taken design documents and drawings, and the Final Safety Analysis Report (FSAR).

\subsection{Ownership of This SDD}

The CVDF Design Authority assigned to the de-ionized water system is responsible for the accuracy and technical content of this SDD. Any questions on the system or content of this document shall be resolved through the design authority.

\subsection{Acronyms}

$\begin{array}{ll}\text { ALARA } & \text { As Low As Reasonably Achievable } \\ \text { ANSI } & \text { American National Standards Institute } \\ \text { ASME } & \text { American Society of Mechanical Engineers } \\ \text { ASTM } & \text { American Society for Testing and Materials } \\ \text { CFR } & \text { Code of Federal Regulations } \\ \text { CVD } & \text { Cold Vacuum Drying } \\ \text { DOE } & \text { U.S. Department of Energy } \\ \text { FSAR } & \text { Final Safety Analysis Report } \\ \text { GOV } & \text { Gas-Operated Valve } \\ \text { gpm } & \text { Gallons per Minute } \\ \text { MCO } & \text { Multi-Canister Overpack } \\ \text { NEMA } & \text { National Equipment Manufacturers Association } \\ \text { NFPA } & \text { National Fire Protection Association }\end{array}$


SNF-3078 Rev 0

LCV

PCV

psig

PWC

SAR

SDD

SCIC

SNF

SNM

SRV

TBD

TEMA

TSR

Level control valve

Pressure Control Valve

Pounds per square inch gauge

Process Water Conditioning

Safety Analysis Report

System Design Description

Safety-Class Instrumentation and Control

Spent Nuclear Fuel

Special Nuclear Materials

Safety Relief Valve

To Be Determined

Tank Equipment Manufacturers Association

Technical Safety Requirement 


\subsection{GENERAL OVERVIEW}

This section provides a general overview of the de-ionized water system. Section 2.1 describes the system functions, Section 2.2 states the de-ionized system classification, and Section 2.3 outlines the basic operation of the de-ionized system.

\subsection{System Functions}

\subsubsection{Normal Process Functions}

The de-ionized water system is used to provide clean, conditioned water, free from contaminants, chlorides and iron for the CVD Facility. Potable water is supplied to the de-ionized water system, isolated by a backflow prevention device. After the de-ionization process is complete, via a packaged de-ionization unit, de-ionized water is supplied to the process de-ionization unit. The de-ionization unit is sized for a minimum flow of 5 gallons per minute (gpm). The unit is located in the process access area storage room. The de-ionized unit stays online during the life of the project.

\subsubsection{Safety Functions}

There are no safety functions listed in Chapter 4 of the CVD Facility FSAR for the de-ionized system.

\subsection{System Classification}

The de-ionized system is designated as "general service" and is designed as Performance Category 1.

\subsection{Basic Operational Overview}

This section gives a brief discussion of how the de-ionized system operates. Figure $2-1$ is a simplified diagram of the de-ionized system.

\subsubsection{Basic Design Overview}

The de-ionized water system is fed from the potable water supply in the de-ionized water equipment room (Room 120) through a reduced pressure backflow assembly. De-ionized water is supplied to the process system via a packaged de-ionized water unit. The de-ionized water conditioning units will be leased from Culligan ${ }^{\mathrm{TM}}$, and these units will supply a minimum of 5 gpm of de-ionized water. Isolation valves on either side of the de-ionized unit are provided to facilitate changeout. The de-ionized unit has a positive visual indication and local alarm when the outlet conductivity exceeds $5 \mu \mathrm{ohms}$. After the de-ionized unit, the system has two holding tanks for storage of de-ionized water. The storage of the de-ionized water is to accommodate peak loads. The de-ionized water is then run through a pressure control valve (PCV) to limit the 
Figure 2-1. General Layout of De-ionized Water System

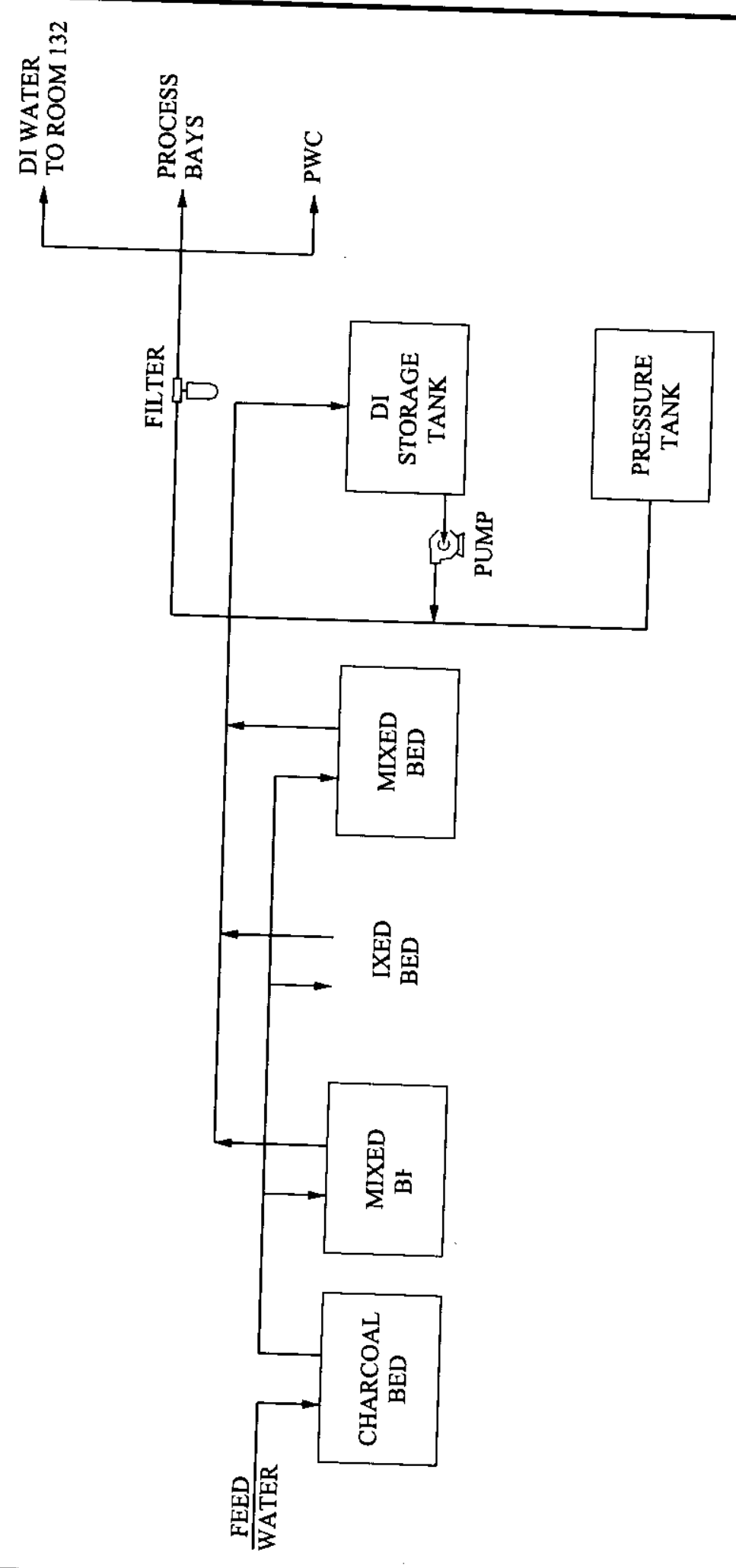


downstream pressure to 20 pounds per square inch gauge (psig). The de-ionized water system then diverts the de-ionized water to the CVD Facility process equipment.

\subsubsection{Basic Operational Overview}

The de-ionized water system is used to produce and distribute de-ionized water throughout the CVD Facility. The de-ionized water system provides de-ionized water to the Process Water Conditioning (PWC) system, to the Multi-Canister Overpack (MCO) for flushing the connectors, and to the tempered water (annulus) system (TWS). The de-ionized water system is supplied from the potable water supply. The de-ionized water system removes contaminants from the potable water. The de-ionized units will be required to provide 10,000 gallons (gals) of deionized water with a conductance of less than $5 \mu$ ohms between changeouts. 


\subsection{REQUIREMENTS AND BASES}

\subsection{General Requirements}

Operational and functional requirements are taken from HNF-SD-SNF-DRD-002, Spent Nuclear Fuel Project Cold Vacuum Drying Facility Design Requirements, Section 6.0, "Facility Design Requirements."

\subsubsection{System Functional Requirements}

Functional requirements of the de-ionized water system include design requirements, safety requirements, environmental requirements, mission critical requirements, and general requirements.

\subsubsection{Design Requirements.}

1. Requirement. De-ionized water shall be supplied to each process bay to supply the TWS and rinsing of the PWC system piping.

Basis: HNF-SD-SNF-DRD-02, Rev. 4, Section 6.6.4.3. The requirements were based on process knowledge and engineering judgement.

How the system meets requirements: The de-ionized water is supplied to the process via the de-ionized units leased from Culligan ${ }^{\mathrm{TM}}$. All instrumentation, piping, and components necessary to control the de-ionized water flow are also supplied as part of the system.

2. Requirement. De-ionized water shall be supplied to the process system via a packaged de-ionized water unit.

Basis: HNF-SD-SNF-DRD-02, Rev. 4, Section 6.6.4.3. The decision to use a packaged unit is based on available expertise and cost equipment.

How the system meets requirements. The de-ionized water is supplied to the process via the de-ionized units leased from Culligan ${ }^{\mathrm{TM}}$. All instrumentation, piping, and components necessary to supply the de-ionized water are also supplied as part of this system.

3. Requirement: Make-up water shall be drawn from the potable water supply through a reduced pressure backflow assembly.

Basis: HNF-SD-SNF-DRD-002, Rev. 4, Section 6.6.4.3. This requirement will prevent backflow contamination of the potable water system. 
How the system meets requirements: The water supply to the de-ionized system is provided from the reduced pressure backflow assembly PW-RPBP-9021 on drawing H-1-82222, sheet 1 .

\subsubsection{Safety Requirements}

3.1.1.2.1 Safety Class Requirements. There are no safety class requirements for the de-ionized water system.

3.1.1.2.2 Safety Significant Requirements. There are no safety significant requirements for the de-ionized water system.

3.1.1.2.3 Other Safety Requirements. There are no other safety requirements for the de-ionized water system.

3.1.1.3 Environmental Requirements. There are no environmental requirements for the de-ionized water system.

3.1.1.4 Mission-Critical Requirements. There are no mission-critical requirements for the de-ionized water system.

3.1.1.5 General Requirements. General requirements are presented by subsystem in Section 3.1.2.

\subsubsection{Subsystem and Major Components}

The de-ionized system consists of de-ionizer units, tanks, pumps, filters, valves, instrumentation and piping that route the de-ionized water to the PWC system, to the MCO, and to the TWS. The de-ionizer units are leased from Culligan ${ }^{\mathrm{TM}}$.

3.1.2.1 Specific Requirements: Specific requirements, basis for requirements, and a description of how the requirement is met are provided below for major systems and components.

1. Requirement: The De-ionizer unit shall be sized for a peak load of $10 \mathrm{gpm}$ and an average load of $1,500 \mathrm{gal} / \mathrm{day}$.

Basis: HNF-SD-SNF-DRD-002, Section 6.6.4.3. This capacity supports maximum operational needs.

How the system meets requirements: The de-ionized water system is sized to deliver $10 \mathrm{gpm}$ and over $1,500 \mathrm{gal} /$ day, based on design calculations and past performance data of similar systems. The de-ionized water system has two holding tanks to accommodate the peak loads.

2. Requirement: The de-ionized water shall have a minimum resistance of $200,000 \mathrm{ohms}$. 
Basis: HNF-SD-SNF-DRD-002, Section 6.6.4.3. This assistance level assumes sufficient removal of conductive constituents.

How the system meets requirements: The resin in the de-ionized unit is capable of producing de-ionized water with a minimum resistance of $200,000 \mathrm{ohms}$. This is based on past operating experience and test data.

3. Requirement: The de-ionizer(s) shall feed a holding tank sized to accommodate peak loads and isolate the de-ionizer from possible contamination backflow and act as the process feed tank.

Basis: HNF-SD-SNF-DRD-002, Section 6.6.4.3. This is based on process knowledge and engineering judgement.

How the system meets requirements: Tank DI-TK-005 on drawing H-1-82222, sheet 1, is sized by using calculation MEI-2288-ME-01-P, which documents and provides the basis for the sizing of the tank. The water supply to the de-ionized water system is provided from the Potable water system through a reduced pressure backflow assembly PW-RPBP-9021 on drawing H-1-82222, sheet 1.

4. Requirement: De-ionized water piping shall be designed and constructed in accordance with American Society of Mechanical Engineers (ASME) B31.3 (Process Skids) or B31.9 (Facility).

Basis: HNF-SD-SNF-DRD-002, Section 6.6.4.3. These are the appropriate national codes for this system.

How the system meets requirements: The de-ionized system is designed to ASME B31.9 for facility distribution and to B31.3 for piping on the process skids.

5. Requirement: The resin shall be capable of handling an inlet concentration of $0.2 \mathrm{ppm}$ iron and $0.3 \mathrm{ppm}$ chlorine on the inlet side of the de-ionizer unit.

Basis: HNF-SD-SNF-DRD-002, Section 6.6.4.3. These requirements are based on past operating experience.

How the system meets requirements: Calculation MEI-2288-ME-01-P documents and analyzes the capabilities of the resin. The results of this calculation are consistent with past operating experience.

6. Requirement: The de-ionized unit shall have a positive visual indication when the outlet conductivity exceeds $5 \mu \mathrm{ohms}$.

Basis: A stated requirement in HNF-SD-SNF-DRD-002, Section 6.6.4.3. This will allow operator action to assure water quality is maintained. 
How the system meets requirements: Visual indication and local alarms are provided by the de-ionized system.

7. Requirement: The de-ionized unit shall produce at least 10,000 gal of de-ionized water with a conductance of less than $5 \mu \mathrm{ohms}$ between changeouts.

Basis: HNF-SD-SNF-DRD-002, Section 6.6.4.3. This will minimize operator action over the facility life.

How the system meets requirements: Calculation MEI-2288-ME-01-P documents and analyzes sizing of the de-ionizer units.

\subsubsection{Boundaries and Interfaces}

The de-ionized water system has the following interfaces:

- $\quad$ The de-ionized water system provides water to the PWC system (SDD SNF-3082).

- The de-ionized water system provides water to MCO for flushing the connectors.

- $\quad$ The de-ionized water system provides water to the TWS (SDD SNF-3085).

- $\quad$ The de-ionized water system interfaces with the Safety-Class Instrumentation and Control (SCIC) system (SDD SNF-3075).

- The de-ionized water receives power for the instrumentation, de-ionized units, and pump from the electrical distribution system (SDD SNF-3075).

- The de-ionized water system is located within the CVD Facility, and Interfaces with the facility and support systems (SDD SNF-3061).

Boundaries are described in the operations section (4.0) of this SDD.

\subsubsection{Codes, Standards, and Regulations}

The following codes, standards, and regulations are utilized in the design, construction, and operation of the CVD, as identified on the drawings, in the specifications, in the operating procedures, and within this SDD.

\subsubsection{Code of Federal Regulations (CFR}

- $\quad 10$ CFR 830.120, "Quality Assurance"

- $\quad 29$ CFR 1910.120, "Occupational Safety and Health Standards." 


\subsubsection{American Society of Mechanical Engineers (ASME)}

- B16.5, Pipe Flanges and Flanged Fittings [American National Standards Institute (ANSI)-approved]

- $\quad$ B16.10, Face to Face and End to End Dimensions of Valves

- B16.11, Forged Steel Fittings, Socket-Welding and Threaded (ANSI-approved)

- B16.21, Nonmetallic Flat Gaskets for Pipe Flanges

- B16.25, Buttwelding Ends

- B16.34, Valves Flanged, Threaded, and Welding End

- B16.39, Malleable Iron Threaded Pipe Unions Classes 150, 250, and 300 (ANSIapproved)

- B18.2.1, Square and Hex Bolts and Screws Inch Series Including Hex Cap Screws and Lag Screws (ANSI-approved)

- B31.9, Process Piping Code

\subsubsection{American Society of Nondestructive Testing}

- $\quad$ SNT-TC-1A, Recommended Practice

\subsubsection{American Society for Testing and Materials (ASTM)}

- A105, Standard Specification for Forgings, Carbon Steel, for Piping Components

- A106, Standard Specification for Seamless Carbon Steel Pipe for High-Temperature Service

- A182, Standard Specification for Forged or Rolled Alloy-Steel Pipe Flanges, Forged Fittings, and Valves and Parts for High-Temperature Service

- A197, Standard Specification for Cupola Malleable Iron

- $\quad$ A240, Standard Specification for Heat-Resisting Chromium and Chromium-Nickel Stainless Steel Plate, Sheet, and Strip for Pressure Vessels

A269, Standard Specification for Seamless and Welded Austenitic Stainless Steel Tubing for General Service 
- A276, Standard Specification for Stainless and Heat-Resisting Steel Bars and Shapes

- A307, Standard Specification for Carbon Steel Bolts and Studs, 60,000 PSI Tensile Strength

- A312/312M, Standard Specification for Seamless and Welded Austenitic Stainless Steel Pipes

- A354, Standard Specification for Quenched and Tempered Alloy Steel Bolts, Studs and Other Externally Threaded Fasteners

- $\quad$ A479, Standard Specification for Stainless and Heat-Resisting Steel Bars and Shapes for Use in Boilers and other Pressure Vessels

- A480, Standard Specification for General Requirements for Flat-Rolled Stainless Heat-Resisting Steel Plate, Sheet, and Strip

- A500, Standard Specification for Cold-Formed Welded and Seamless Carbon Steel Structural Tubing in Rounds and Shapes

- A563, Standard Specification for Carbon and Alloy Steel Nuts

- F593, Standard Specification for Stainless Steel Bolts, Hex Cap Screws, and Studs

- $\quad$ F594, Standard Specification for Stainless Steel Nuts.

3.1.4.5 U.S. Department of Energy (DOE) Standards. All de-ionized pumps, tanks, valves, components, instrumentation, controls, and support structures required to perform the general services are designed and qualified for performance category 1 as defined in DOE-STD-1020-94, Natural Phenomena Hazards Design and Evaluation Criteria for Department of Energy Facilities.

\subsubsection{National Equipment Manufacturers Association (NEMA)}

- $\quad 250$, Enclosures for Electrical Equipment

\subsubsection{National Fire Protection Association (NFPA)}

- 70, National Electrical Code 


\subsubsection{Operability}

There are no technical safety requirements listed in the CVD Facility Safety Analysis Report (SAR); therefore, this section does not apply to the de-ionized water system.

\subsection{Special Requirements}

\subsubsection{Radiation and Other Hazards}

The primary radiation hazard in the facility is from the Spent Nuclear Fuel (SNF) contained within the MCO. Radiation hazards specifically associated with the de-ionized water system are addressed in Section 3.2.2.

\subsubsection{ALARA}

Engineering controls and maintenance features have been considered and incorporated into the design of the CVD Facility. Engineering controls appropriate to the de-ionized water system include:

- $\quad$ Piping and components designed to minimize holdup and accumulation of contaminants.

- Equipment design and layout to allow operation, servicing, and replacement in lowradiation areas.

- $\quad$ Automation of the process to allow remote operation from a low-radiation area.

- $\quad$ Local shielding to minimize operator dose rates.

Essential elements of the As Low As Reasonably Achievable (ALARA) program are defined in G-10 CFR 835/B2-Rev.0, Implementation Guide for Use with Title 10, CFR, Part 835 Occupational Radiation Protection. The ALARA program implemented at the SNF Project facilities is documented in SNF-AP-5-006, ALARA Goals, Training, and Control Level Administration; SNF-AP-5-012, Radiological ALARA Work Planning Process; and SNF-AP-5-013, Radiological ALARA Process, which establish lines of responsibility for administering ALARA practices. A CVD Facility coordinator and committee oversee the CVD Facility ALARA practices.

\subsubsection{Nuclear Criticality Safety}

This section does not apply to this system. 


\subsubsection{Industrial Hazards}

The de-ionized water system design has been evaluated against and complies with the required codes, standards, and regulations for industrial safety and hygiene. Operating and maintenance procedures will identify additional practices to assure worker protection from industrial hazards.

\subsubsection{Operating Environment and Natural Phenomena}

The de-ionized water system shall be capable of normal operation in an environment of $40^{\circ} \mathrm{F}$ to $90^{\circ} \mathrm{F}$, ambient pressure, 0 to 80 percent relative humidity, and with air borne dirt/dust. The deionized water system is protected from high winds and tornadoes by the structure of the CVD Facility. The placement and design of the CVD Facility provides flooding, lightning, and snow load protections.

\subsubsection{Human Interface Requirements}

The de-ionized water system operates in an automatic mode. Human interface is limited, but may include activation of the system, periodic surveillance, and maintenance functions. The equipment and procedures have been evaluated for appropriate Human Factor considerations.

\subsubsection{Specific Commitments}

All aspects of the de-ionized water system are in compliance with the Hanford Federal Facility Agreement and Consent Order (Ecology 1994), and with applicable federal, state, and local laws and American Indian treaty rights.

\subsection{Engineering Disciplinary Requirements}

\subsubsection{Civil and Structural}

The civil/structural requirements have been implemented by the facility design that is described in SDD SNF-3061.

\subsubsection{Mechanical and Materials}

All de-ionized water system process equipment vessels and tanks are designed and fabricated per Boiler and Pressure Vessel Code (ASME 1995), Section VIII, "Rules for Construction of Pressure Vessels," Division 1, and Heat Exchangers Mechanical Standards [Tank Equipment Manufacturers Association (TEMA) 1992].

All de-ionized water system process equipment piping and valves are designed and fabricated per ANSI/ASME B31.9, Process Piping Code, and ANSI/ASME B16 Standards series, Fittings, Flanges, and Valves. This is in accordance with the approach National Codes and Standards. 


\subsubsection{Chemical and Process}

Not applicable to the de-ionized water system.

\subsubsection{Electrical Power}

Electrical Power requirements have been implemented by SDD SNF-3075 for the electrical system.

\subsubsection{Instrumentation and Control}

All instrumentation and control components have been designed and fabricated per ANSI/ISA-S5.1, Instrument Symbols and Identification; ANSI/ISA-S5.4, Instrument Loop Diagrams; ANSI/ISA-S18.1, Annunciator Sequences and Specifications; and ANSI/ISA-S20, Specification Forms for Process Measurement and Control Instruments Primary Elements and Control Valves, and all other requirements noted below have been incorporated into the design media identified in Appendix B.

\subsubsection{Computer Hardware and Software}

Computer hardware and software requirements are covered under the SDDs for the monitor control system (MCS) and SCIC. See SNF-3090, CVD Facility Monitoring and Control System Design Description, and SNF-3091, CVD Facility Safety Class Instrumentation and Control System Design Description.

\subsubsection{Fire Protection}

There are no fire protection requirements associated with the de-ionized water system.

\subsection{Testing And Maintenance Requirements}

\subsubsection{Testability}

Testing features have been designed into the system to implement testing requirements. System design has also incorporated features for verifying system operability as described in he component requirements.

\subsubsection{Technical Safety Requirement (TSR)-Required Surveillances}

There are no TSR-required surveillances applicable to the de-ionized water system.

\subsubsection{Non-TSR Inspections and Testing}

Functional performance criteria shall be tested on a periodic basis to ensure operability of systems and components. All testing shall be performed between MCO processing cycles to the maximum extent possible, and shall have minimum impact on processing availability. 
System operability shall be verified by surveillance of the system's operability status and component states (e.g. valve position, supply pressure, system alarms) before enabling the system for each MCO process cycle. The system shall require additional periodic surveillance if required to be operational for an extended period of time beyond one normal processing cycle.

The de-ionized water system shall have sufficient testability designed into it to permit the periodic measurement and calibration of all setpoints and adjustments that affect the manner in which the de-ionized water system performs. Periodic testing of de-ionized water system structures, systems, and components (SSCs) is dictated by the requirements of the individual components according to the respective manufacturer's recommended schedule and practice.

\subsubsection{Maintenance}

Regularly scheduled maintenance activities requiring system shutdown have been avoided in the design. System maintenance activities shall be limited to maintenance caused by failures. System design shall incorporate features (e.g. sufficient working space around the component for repair or removal) for ease of maintenance. To the maximum extent possible, the design shall allow major components and energy sources to be easily isolated in order to meet log and tag requirements.

\subsection{Other Requirements}

\subsubsection{Security and Special Nuclear Material (SNM) Protection}

There are no Security or SNM Protection requirements associated with the de-ionized water system.

\subsubsection{Special Installation Requirements}

There are no special installation requirements for the de-ionized water system.

\subsubsection{Reliability, Availability, and Preferred Failure Modes}

The de-ionized water system stays online during the life of the project, and no maintenance activities are required during the CVD Facility three-year operating period.

\subsubsection{Quality Assurance}

The de-ionized water system fabrication quality assurance/control program is based on the safety classification of the SSCs as detailed in the SNF Project CVD Facility Master Equipment List (SNF-4148) and application of a graded approach as described in the Project Hanford Quality Assurance Program Description (HNF-MP-599). 


\subsection{SYSTEM DESCRIPTION}

\subsection{Configuration}

Each process bay is serviced by the de-ionized water system. The de-ionized water system components are described below.

\subsubsection{Description of System, Subsystems, and Major Components}

The de-ionized water system operates continually during CVD Facility operations. The deionized water system delivers the necessary water purity and quantity to all the process equipment. The de-ionized water system consists of tanks, valves, filters, pumps, piping, and packaged, leased, de-ionization units. Refer to the P\&ID and mechanical layout drawings listed in Appendix B to gain a better understanding of the arrangement/configuration of the following subsystems.

For convenience and ease of discussion, the de-ionized water system is described in two separate sections; the de-ionized units and tanks are described in Section 4.1.1.1, and the distribution systems are described in Section 4.1.1.2. Figure 2-1 provided a layout of the de-ionized water system.

\subsubsection{De-ionized Units and Tanks (Figure 4-1)}

- $\quad$ The potable water supply feeds the de-ionized units through flow control valve FCV9012 set at $8 \mathrm{gpm}$. The potable water flows through isolation valve DI-V-50 into the charcoal filter.

- The charcoal filter is designed to remove organics from the potable water feed. The mixed bed de-ionizer tanks will remove the iron and chlorine from the potable water feed. The three beds will be piped in parallel with one online at any time. The mixed beds shall each have a $3.6 \mathrm{ft}^{3}$ capacity.

- Line DI-022-SS-1" connects to level control valve LCV-9002. The LCV controls the fluid level in the de-ionized water process tank DI-TK-005. The LCV receives input from sensors in the tank that allow the LCV to keep the fluid level between $10-1 / 2$ inches and $37-1 / 2$ inches from the bottom.

- DI-TK-005 is the process feed tank. It holds 150 gal and has several instruments attached. DI-TK-005 has a level switch high LSH-9008, level switch low LSL-9011, and float control sensor for the LCV. The LSH has a level alarm high attached that sounds a local alarm when the level in the tank reaches 41 inches from the bottom. The LSL is located $10-1 / 2$ inches from the bottom of DI-TK-005. These instruments interface with the MCS. 
Figure 4-1. De-ionized Units and Distribution

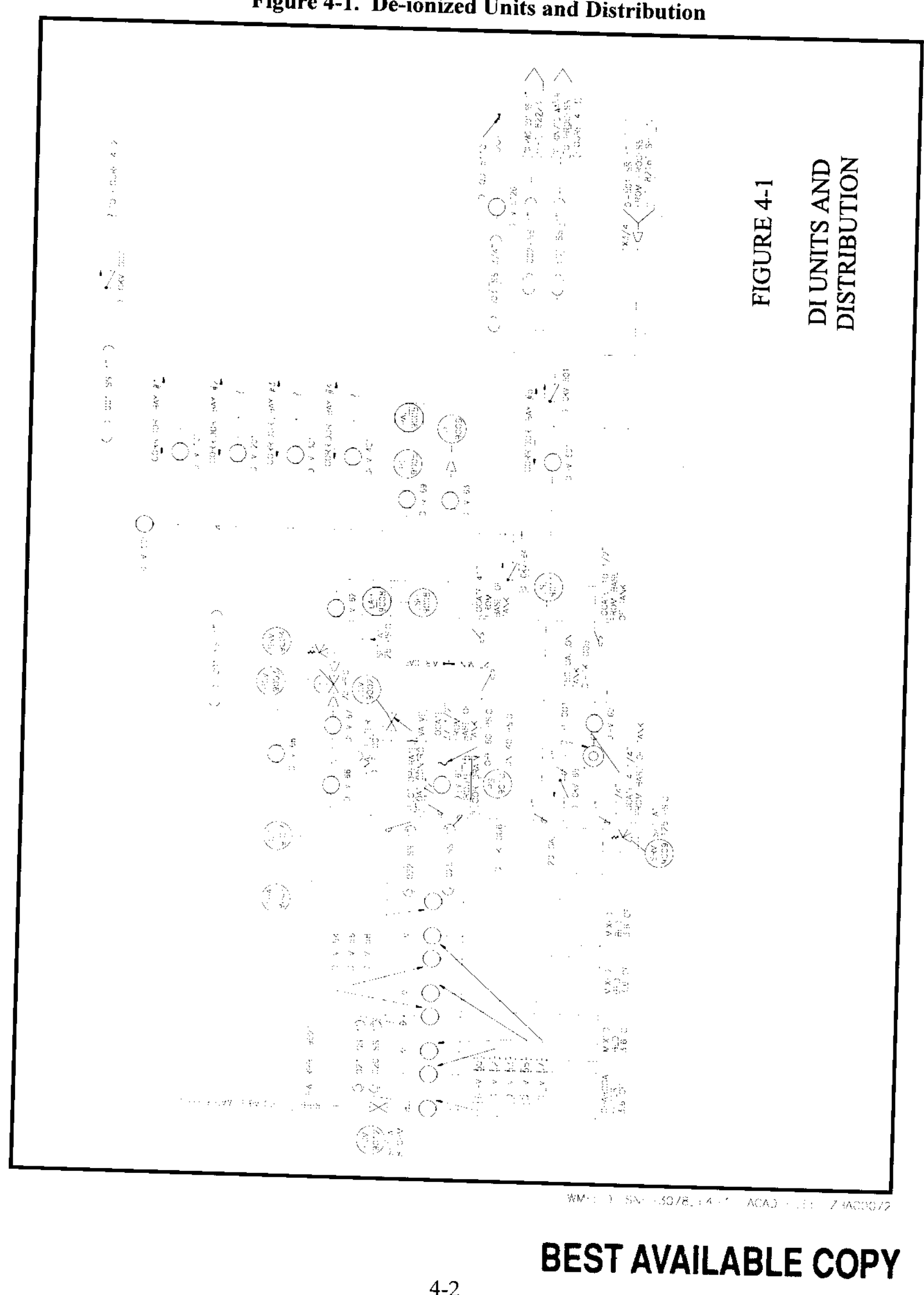


- DI-TK-005 is connected to pump DI-P-001 through isolation valve DI-V-60. Pump DIP-001 supplies de-ionized water through check valve DI-CKV-65 into a tee. One branch of the tee feeds de-ionized tank DI-TK-006. This tank is a 20 gal tank pressurized to 30 psig. Safety relief valve SRV-9009 in the feed to tank line DI-TK-006 is set at 125 psig.

- The other branch of the tee (line DI-025-SS-1") connects with isolation valve DI-V-66. DI-025-SS-1" has pressure switch PS-9010 that monitors pressure and turns off pump DIP-001 when the pressure reaches 60 psig and turns on pump DI-P-001 when the pressure drops to 40 psig.

- Line DI-025-SS-1" connects to the final filter DI-F-001. A bypass valve (DI-V-68) and two isolation valves (DI-V-66 and DI-V-67) are provided for the filter. The filter is isolated by closing DI-V-66 and DI-V-67. This enables the filter to be changed when needed, while the system continues to function.

- $\quad$ Pressure Control Valve PCV-9003, set at 20 psig, is located downstream of the final filter DI-F-001. An isolation valve DI-V-62 and check valve DI-CKV-64 are located downstream of the PCV. The system distribution line DI-001-SS-1" is located downstream of check valve DI-CKV-64.

- The line between DI-V-62 and DI-CKV-64 has two isolation valves branched off to the side. The first isolation valve DI-V-69 is connected to a pressure transmitter PT-9005, which is connected to pressure alarm low PAL-9005. PAL-9005 sounds a local and a MCS alarm when the pressure drops below the setpoint. The second isolation valve DI$\mathrm{V}-63$ is connected to a pressure indicator PI-9006.

\subsubsection{Distribution System}

- Line DI-001-SS-1" is the distribution header for the de-ionized water system. The discussion of the distribution system will be limited to the de-ionized water feed to PWC and one process bay (since each bay is similar).

- $\quad$ PWC/De-ionized Water System Interface (Figure 4-2)

- DI-001-SS-1" feeds Room 132 through isolation valve DI-V-005. In Room 132, DI-001-SS-1" connects line DI-004-SS- 1/2" through check valve DI-CKV-007 (see Figure 4-3). DI-004-SS- 1/2" flows both directions from the connection with DI-001-SS-1". In one direction, DI-001-SS-1" branches into DI-005-SS-1/2" and DI-006-SS-1/2". In the other direction, DI-001-SS-1" flows through normally closed isolation valve DI-V-011.

- Line DI-005-SS-1/2" provides de-ionized water to tank PWC-4001 through normally closed isolation valve DI-V-012 and check valve DI-CKV-009. Line DI-006-SS-1/2" provides flow to pump PWC-P-4001 through normally closed isolation valve DI-V-013 and check valve DI-CKV-010. 
- Downstream of isolation valve DI-V-011, Line DI-004-SS-1/2" flows through check valve DI-CKV-008 and a flexible hose connection to three-way valve DI$\mathrm{V}$-032. The normal condition is the flexible hose not installed, lines capped, and valve DI-V-032 aligned to block flow to the hose connection.

- Three-way valve DI-V-032 is located in line DI-014-SS-1/2". One branch from valve DI-V-032 flows through normally open, air-operated valve DI-V-008 and then either to tanks PWC-TK-4032 and PWC-TK-4033 through gas-operated valve GOV-4057 or to tank TWC-TK-4001 through a branch connection (DI-013SS-1/2") and normally closed isolation valve DI-V-031.

- $\quad$ The other branch from DI-V-032 flows through normally closed isolation valve DI-V-007 which connects to the PWC system through line PWC-006-SS-11/2". Line PWC-006-SS-11/2" connects to sample flask PWC-SMP-4039.

- $\quad$ Gas-operated valve GOV-4057 is a fail close valve controlled by the SCIC system. Instrument air is supplied to valve GOV-4057 through manually operated (hand switch HS-4057) solenoid valve SOV-4057.

- $\quad$ De-ionized water feed to the process bays (Figures 4-3, 4-4, and 4-5):

- $\quad$ Process bay \#5 will be discussed. The other process bays are similar. DI-001-SS1 " connects to isolation valve DI-V-501 and check valve DI-CKV-501 (see Figure 4-1). Downstream of check valve DI-CKV-501, line DI-501-SS-1" feeds de-ionized water to process bay \#5. A branch line (DI-002-SS-1") provides another interface with the PWC system in process bay \#5. The other process bays do not have this line split. Line DI-501-SS-1" connects with a gage root valve and flow indicator FI-1531 set at $6 \mathrm{gpm}$ (see Figure 4-4).

- $\quad$ Before DI-501-SS-1" connects to the gage root valve and FI-1531, line DI-502SS-1" branches off DI-501-SS-1". DI-502-SS-1" connects to check valve DICKV-5129 and valve DI-V-5049 which connects to TW-TK-3512 (see Figure 45). This is the interface with the TWS.

- $\quad$ After FI-1531 (see Figure 4-3) DI-501-SS-1" connects with check valve DI-CKV5011 , which is connected to GOV-1501. GOV-1501 is a fail close valve that is controlled by the MCS. The instrumentation included to control this valve are a position switch ZS-1501, hand switch HS-1501, hand safety switch HSS-1501, and a solenoid operated valve SOV -1501 . 
SNF-3078 Rev 0

Figure 4-2. PWC System/De-ionized Water System Interface

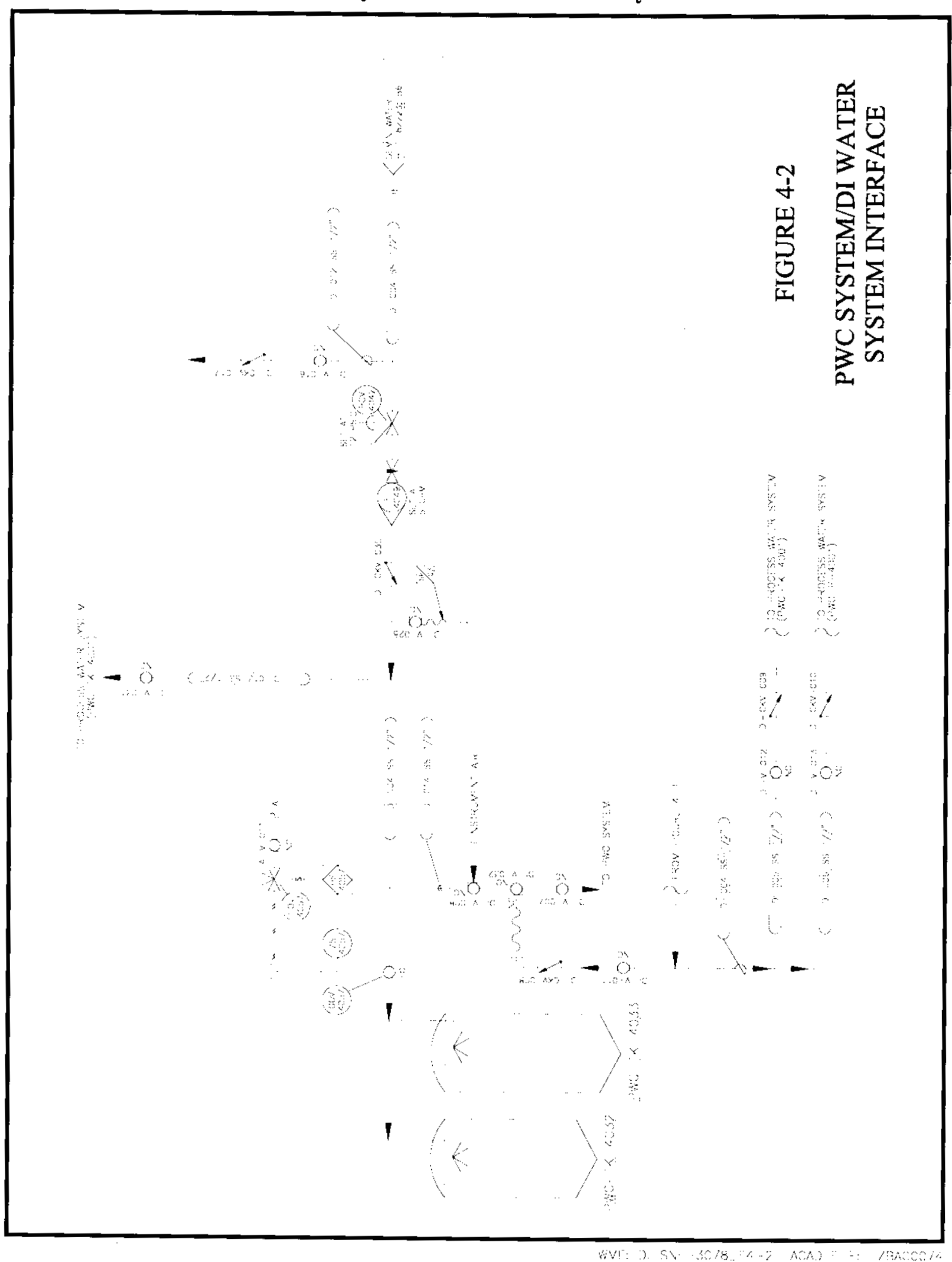


SNF-3078 Rev 0

Figure 4-3. De-ionized Water Flush to MCO

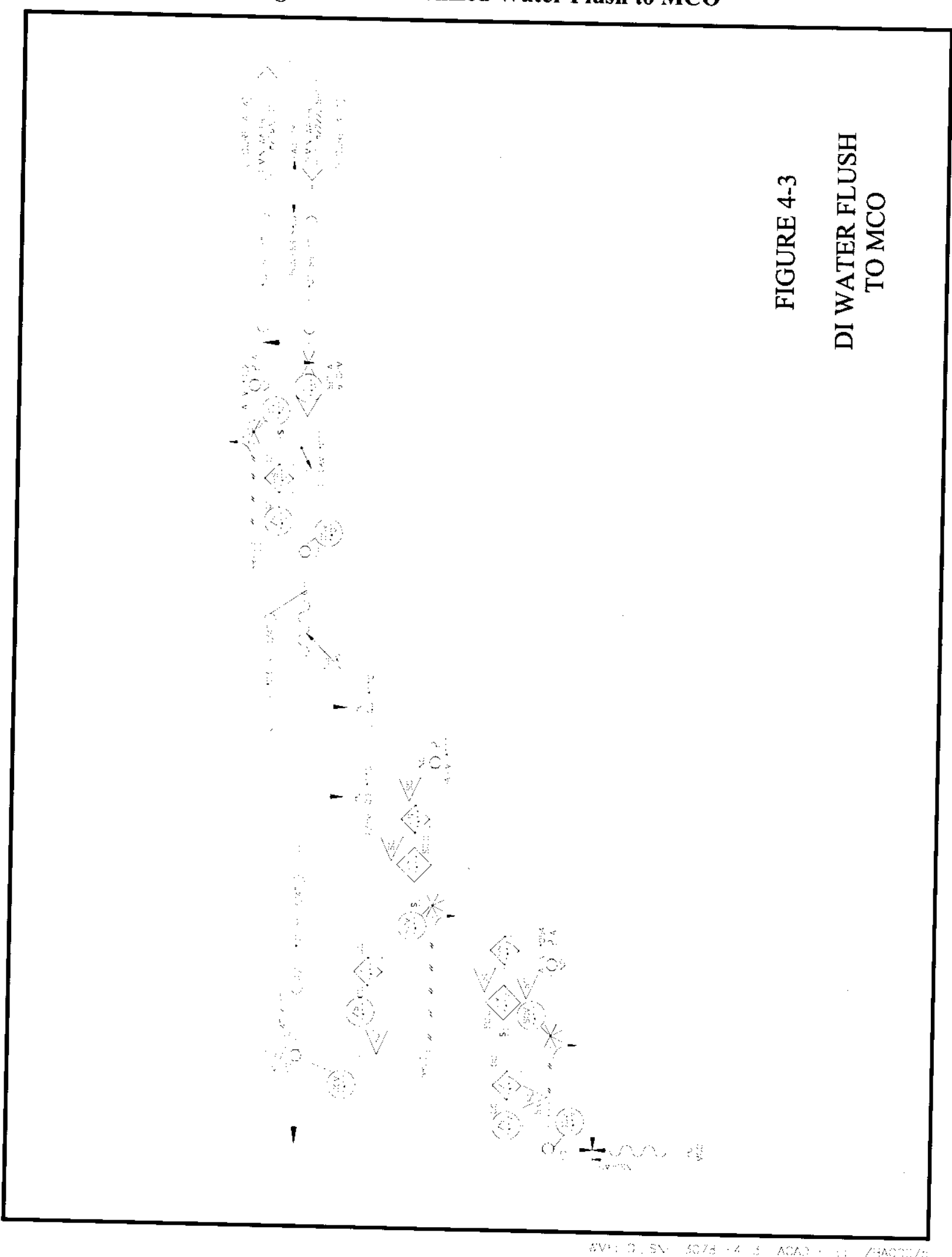




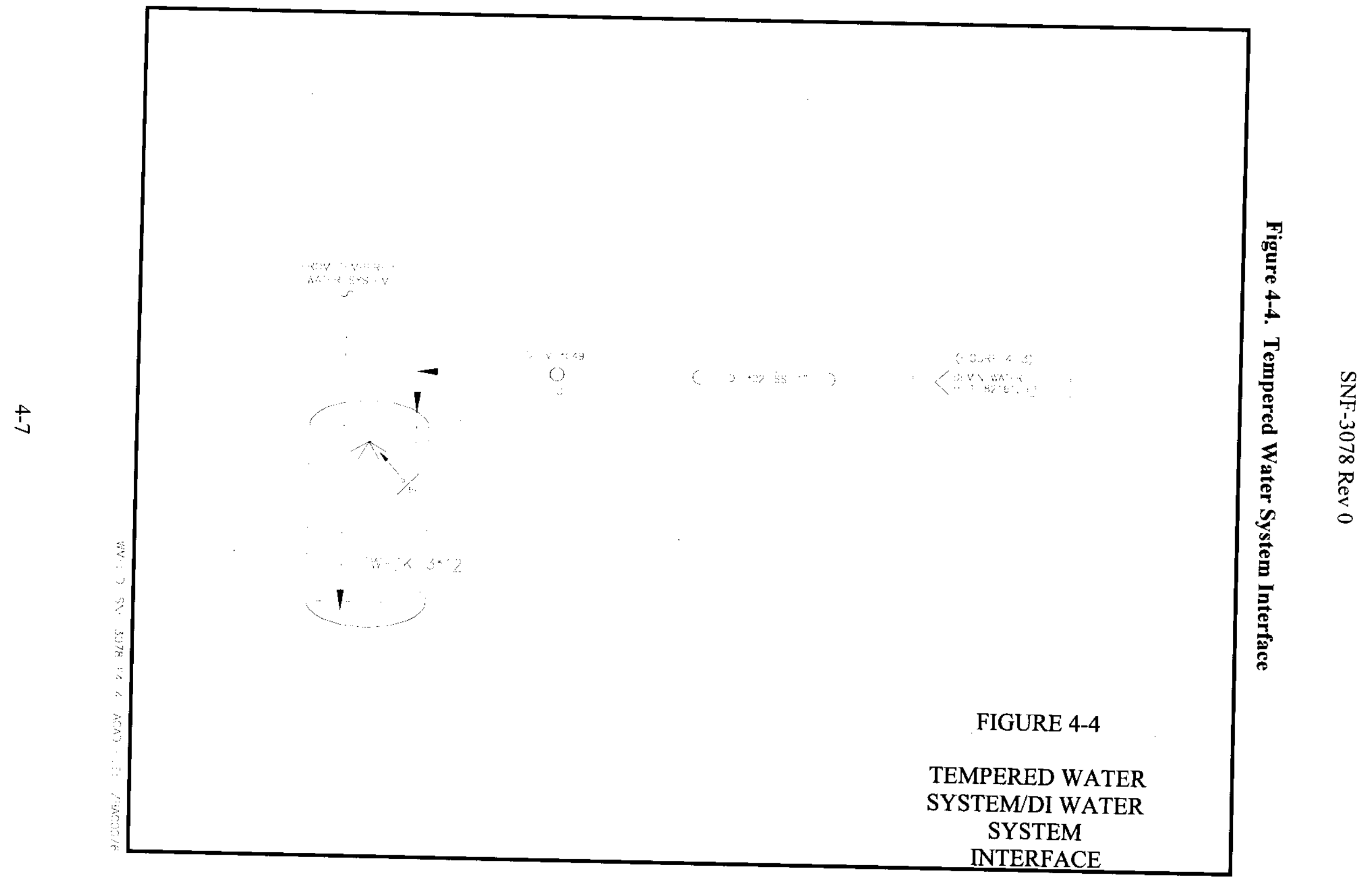


Figure 4-5. DI/HE Interface

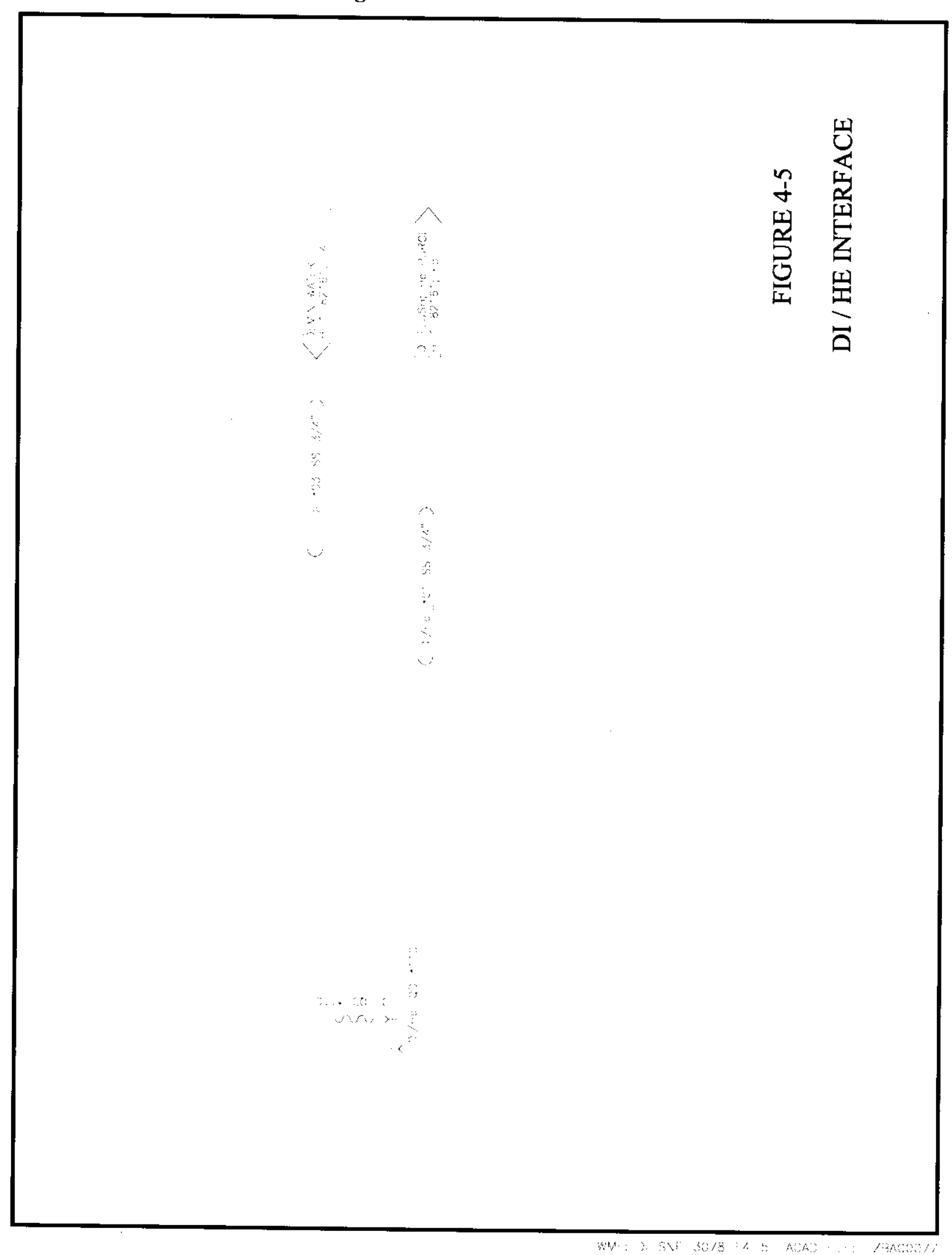


SNF-3078 Rev 0

- DI-501-SS-1" connects with line DI-503-SS- 3/4", which connects to a flexible hose between system boundaries and then connects to a quick disconnect DI-QD5110 (see Figure 4-3).

- When connected DI-QD-5110 connects to DI/He-QD-5110 which connects to line $\mathrm{DI} / \mathrm{He}-501-\mathrm{SS}-3 / 4$ ". DI/He-501-SS- 3/4" is connected to gas operated valve GOV1511. GOV-1511 is a fail close valve that is controlled by the SCIC system. The instrumentation to control this valve includes a position switch ZS-1511, position indicator ZI-1511, hand switch HS-1511, and a solenoid operated valve SOV1511 .

- When downstream of valve GOV-1511, line DI/He-501-SS- 3/4" is connected to another gas-operated valve, GOV-1517. GOV-1517 is a fail close valve that is controlled by the SCIC system. The instrumentation to control this valve includes a position switch ZS-1517, hand switch HS-1517, position indicator ZI-1517, and a solenoid operated valve SOV-1517.

\subsubsection{Boundaries and Interfaces}

The main de-ionized water system interfaces are with the PWC system, MCO, SCIC, TWS, and the potable water system. The location of each of these interfaces has been discussed in Section 4.1.1. The de-ionized water system has five different interfaces with the PWC system; they are with PWC-TK-4001, PWC-TK-4032, PWC-TK-4033, PWC-006-SS-1 1/2", and PWC-014-SS-1". The de-ionized water system interfaces with the MCO through the DI/He purge line connected to the MCO. The SCIC interface is through the GOVs that control the flow of de-ionized water. The TWS interface with the de-ionized water system is de-ionized water line that is provided to each process bay tempered water tank. The potable water system provides the makeup water for the de-ionized water system.

The de-ionized water system interfaces with the CVD Facility electrical system. The electrical equipment for the de-ionized water system includes the de-ionized units, pump, and instrumentation, which are wired to the CVD Facility electrical power.

The de-ionized water system interfaces with the MCS through the instrumentation that is used to control and operate the de-ionized units. The de-ionized water system provides a number of inputs to the MCS. The MCS interfaces have been discussed in Section 4.1.1.

\subsubsection{Physical Location and Layout}

The de-ionized water system is located in the de-ionized water equipment room (Room 120). The de-ionized water system is bounded by the potable water supply line located in the deionized water equipment room (120) and the end use connections at the process skids in each bay and at the connection to the PWC system in Room 132. 


\subsubsection{Principles of Operation}

The de-ionized water system runs continuously in an automatic mode. The de-ionized water is supplied from the potable water supply. The de-ionized water system provides contaminate free water to the PWC, MCO, and TWS. De-ionized water is supplied to the process system via a packaged de-ionized water unit. The de-ionized unit is sized for a peak load of $10 \mathrm{gpm}$ and an average load of $1,500 \mathrm{gal} /$ day. The resin in the de-ionized water unit is capable of handling an inlet concentration of $0.2 \mathrm{ppm}$ iron and $0.3 \mathrm{ppm}$ chlorine on the inlet side of the de-ionized unit. The de-ionized unit is capable of producing 10,000 gal of de-ionized water with a conductance of less than $5 \mu \mathrm{ohms}$ between changeouts. The de-ionized water produced has a minimum resistance of $200,000 \mathrm{ohms}$. The de-ionized unit has positive visual indication and local alarm when the outlet conductivity exceeds 5 oohms. After the de-ionized unit, the system provides the de-ionized water to the interfaces.

\subsubsection{System Reliability}

Not applicable to the de-ionized water system.

\subsubsection{System Control Features}

Not applicable to the de-ionized water system.

4.1.6.1 System Monitoring. The de-ionized water system contains a number of inputs to the MCS. The MCS does not control the de-ionized water system, it only provides for system monitoring.

4.1.6.2 Setpoints and Ranges. Nominal settings and system parameters for the de-ionized water system as based on initial design are as follows:

- $\quad$ PCV-9003 set at 20 psig, PCV-4042 set at 12 psig.

- $\quad$ Pressure relief valve SRV-9009 set at 125 psig.

- $\quad$ Pressure switch PS-9010 is set at 60 psig for the off pressure and 40 psig for the on pressure.

Flow Indicator (FI-1531) - 6 gpm.

\subsection{Operations}

The CVD Facility operation is a batch process. Operation of the de-ionized water system itself is performed in conjunction with all the interface systems described in Section 4.1.2. For a detailed sequence of operations, see the operations manual, HNF-2356, and Appendix D of W-441-P003, The Fabrication and Procurement Specification for the Monitoring and Control System.

Detailed operating steps are not presented here. 


\subsubsection{Initial Configurations (Pre-startup)}

A Test specification will be developed identifying the requirements for all testing associated with this system. This specification will address factory acceptance tests (FATs) and construction acceptance tests (CATs), and pre-startup tests.

\subsubsection{System Startup}

Startup, alignment, prerequisite testing, and formal start up activities will be identified in the test specification.

\subsubsection{Normal Operations}

Normal operation of the de-ionized water system is described in Section 4.1.4.

Operational procedures providing detailed information on operating modes and activities (including alarm response, shutdown, etc.) will be developed.

\subsubsection{Off-Normal Operations}

The only identified off-normal event would be if the fire suppression system fails to turn off after initiation. This event would eventually cause the retention basin to overflow. Manual intervention is required in this case, and the appropriate actions will be identified in the alarm response procedures.

\subsubsection{System Shutdown}

There are no unique shutdown requirements for this system.

\subsubsection{Safety Management Programs and Administrative Controls}

The necessary administrative control procedures will be developed and incorporated into the operating procedures to prevent manually draining contaminated water from a sump to the retention basin.

These controls and procedures are in accordance with the spent fuel integrated safety management plan.

\subsection{Testing And Maintenance}

The de-ionized water system is designed to operate through the design life of the equipment (five years) without regularly scheduled facility shutdowns for maintenance. System maintenance activities are limited to maintenance due to failures. Additional maintenance activities and procedures may be scheduled if system surveillance, testing, or maintenance identifies additional requirements. All maintenance is performed under controlled procedures using approved (quality assurance-qualified) equipment and materials. Only spare parts meeting design criteria are procured and used. The equipment has been designed for efficient maintainability. The 
surveillance, testing, and maintenance of the system are achieved at minimum cost and level of support services per DOE Order 6430.1A, Section 1300-12.4.10.

\subsubsection{Temporary Configurations}

There are no temporary configurations approved for the de-ionized water system.

\subsubsection{TSR-Required Surveillances}

There are no TSR-required surveillances associated with the de-ionized water system.

\subsubsection{Non-TSR Inspections, and Testing}

Surveillance and in-service inspections of equipment are made per the manufacturer's recommendations. As dictated by the equipment operating manuals, surveillance is incorporated into the de-ionized water system standard operating procedures. Operators are expected to report all occurrences to their supervisors who in turn initiate an occurrence investigation. Accommodations have been made for both manual and electronic inspection of de-ionized water system equipment.

\subsubsection{Maintenance}

Maintenance features, including replacement of valves and piping connected to the primary barrier, are designed so that these activities are carried out under heating, ventilation, and air conditioning in-flow or isolation. Equipment and components have been located away from potentially contaminated areas, whenever practical, to reduce contact with contamination and to minimize situations causing breach of containment. Modular design has been incorporated to facilitate change-out of systems requiring timely repair and/or special skills, and to reduce problems associated with equipment removal and repair. Commercial equipment, components, and parts are used wherever feasible to reduce procurement, maintenance, training, and inventory costs.

\subsubsection{Equipment Calibration}

All equipment must be calibrated and recalibrated according to the respective manufacturer's recommended schedule and practice. Calibration and test connections are provided to enable inservice testing and calibration when practical. 
SNF-3078 Rev 0

Appendix A

Source Documents

A-1 


\section{A.1 INDUSTRY STANDARDS AND CODES}

ANSI/ASME B16 Standards series, 1996, Fittings, Flanges and Valves, American Society of Mechanical Engineers, New York, New York.

ANSI/ASME B16.5, 1996, Pipe Flanges and Flanged Fittings, American Society of Mechanical Engineers, New York, New York.

ANSI/ASME B16.10, 1992, Face to Face and End to End Dimensions of Valves, American Society of Mechanical Engineers, New York, New York.

ANSI/ASME B16.11, 1996, Forged Steel Fittings, Socket-Welding and Threaded, American Society of Mechanical Engineers, New York, New York.

ANSI/ASME B16.21, 1992, Nonmetallic Flat Gaskets for Pipe Flanges, American Society of Mechanical Engineers, New York, New York.

ANSI/ASME B16.25, 1997, Buttwelding Ends, American Society of Mechanical Engineers, New York, New York.

ANSI/ASME B16.34, 1996, Valves Flanged, Threaded, and Welding End, American Society of Mechanical Engineers, New York, New York.

ANSI/ASME B16.39, 1996, Malleable Iron Threaded Pipe Unions Classes 150, 250, and 300, American Society of Mechanical Engineers, New York, New York.

ANSI/ASME B18.2.1, 1992, Square and Hex Bolts and Screws Inch Series Including Hex Cap Screws and Lag Screws, American Society of Mechanical Engineers, New York, New York.

ANSI/ASME B31.3, 1996, Process Piping Code, American Society of Mechanical Engineers, New York, New York.

ANSI/ASME NQA-1, 1997, Quality Assurance Requirements for Nuclear Facility Applications, American Society of Mechanical Engineers, New York, New York.

ANSI/ISA-S5.1, 1984 (1992), Instrument Symbols and Identification, Instrument Society of America, Research Triangle Park, North Carolina.

ANSI/ISA-S5.4, 1991, Instrument Loop Diagrams, Instrument Society of America, Research Triangle Park, North Carolina.

ANSI/ISA-S18.1, 1979 (1992), Annunciator Sequences and Specifications, Instrument Society of America, Research Triangle Park, North Carolina. 
ANSI/ISA-S20, 1981, Specification Forms for Process Measurement and Control Instruments Primary Elements and Control Valves, Instrument Society of America, Research Triangle Park, North Carolina.

ASME, 1995, Boiler and Pressure Vessel Code, American Society of Mechanical Engineers, New York, New York.

Section II, "Material Specifications, Welding Rods, Part C Electrodes, and Filler Metals"

Section VIII"Division I Rules for Construction of Pressure Vessels"

Section IX "Qualification Standard for Welding and Brazing Procedures, Welders, Brazers, and Welding and Brazing Operators"

ASME B73.1M, 1991, Specification for Horizontal End Section Centrifugal Pumps for Chemical Process, American Society of Mechanical Engineers, New York, New York.

ASME B73.2M, 1991, Specification for Horizontal In-Line Centrifugal Pumps for Chemical Process, American Society of Mechanical Engineers, New York, New York.

ASTM A36, 1993, Standard Specification for Structural Steel, American Society for Testing and Materials, West Conshohocken, Pennsylvania.

ASTM A105, 1996, Standard Specification for Forgings, Carbon Steel, and for Piping Components, American Society for Testing and Materials, West Conshohocken, Pennsylvania.

ASTM A106, 1995, Standard Specification for Seamless Carbon Steel Pipe for High-Temperature Service, American Society for Testing and Materials, West Conshohocken, Pennsylvania.

ASTM A182, 1997, Standard Specification for Forged or Rolled Alloy-Steel Pipe Flanges, Forged Fittings, and Valves and Parts for High-Temperature Service, American Society for Testing and Materials, West Conshohocken, Pennsylvania.

ASTM A197, 1987 (1992), Standard Specification for Cupola Malleable Iron, American Society for Testing and Materials, West Conshohocken, Pennsylvania.

ASTM A240, 1997, Standard Specification for Heat-Resisting Chromium and Chromium-Nickel Stainless Steel Plate, Sheet, and Strip for Pressure Vessels, American Society for Testing and Materials, West Conshohocken, Pennsylvania.

ASTM A269, 1996, Standard Specification for Seamless and Welded Austenitic Stainless Steel Tubing for General Service, American Society for Testing and Materials, West Conshohocken, Pennsylvania. 
ASTM A276, 1997, Standard Specification for Stainless and Heat-Resisting Steel Bars and Shapes, American Society for Testing and Materials, West Conshohocken, Pennsylvania.

ASTM A307, 1993, Standard Specification for Carbon Steel Bolts and Studs, 60,000 psi Tensile Strength, American Society for Testing and Materials, West Conshohocken, Pennsylvania.

ASTM A312/312M, Rev. A, 1995, Standard Specification for Seamless and Welded Austenitic Stainless Steel Pipes, American Society for Testing and Materials, West Conshohocken, Pennsylvania.

ASTM A354, 1997, Standard Specification for Quenched and Tempered Alloy Steel Bolts, Studs and other Externally Threaded Fasteners, American Society for Testing and Materials, West Conshohocken, Pennsylvania.

ASTM A479, 1997, Standard Specification for Stainless and Heat-Resisting Steel Bars and Shapes for Use in Boilers and other Pressure Vessels, American Society for Testing and Materials, West Conshohocken, Pennsylvania.

ASTM A480, 1997, Standard Specification for General Requirements for Flat-Rolled Stainless Heat-Resisting Steel Plate, Sheet, and Strip, American Society for Testing and Materials, West Conshohocken, Pennsylvania.

ASTM A500, 1993, Grade B Specification for Cold Formed, Welded and Seamless Carbon Steel Structural Tubing in Rounds and Shapes, American Society for Testing and Materials, West Conshohocken, Pennsylvania.

ASTM A563, 1996, Standard Specification for Carbon and Alloy Steel Nuts, American Society for Testing and Materials, West Conshohocken, Pennsylvania.

ASTM F593, 1995, Standard Specification for Stainless Steel Bolts, Hex Cap Screws, and Studs, American Society for Testing and Materials, West Conshohocken, Pennsylvania.

ASTM F594, 1991, Standard Specification for Stainless Steel Nuts, American Society for Testing and Materials, West Conshohocken, Pennsylvania.

AWS-D1.1, 1996, Structural Welding Code—Steel, American Welding Society, Miami, Florida.

IEEE-577, 1976 (1992), Standard Requirements for Reliability Analysis in the Design and Operation of Safety Systems for Nuclear Power Generating Stations, Institute of Electrical and Electronics Engineering, Piscataway, New Jersey.

IEEE-603, 1991, Standard for Design Qualification of Safety Systems for Nuclear Power Generating Stations, Institute of Electrical and Electronics Engineering, Piscataway, New Jersey. 
NEMA 250, 1997, Enclosures for Electrical Equipment (1000 V maximum), National Equipment Manufacturers Association, Roslyn, Virginia.

NFPA 70, 1996, National Electrical Code, National Fire Protection Association, Quincy Massachusetts.

SNT-TC-1A, 1996, Recommended Practice, American Society of Nondestructive Testing, Columbus, Ohio.

TEMA, 1982, Heat Exchangers Mechanical Standards, Tubular Exchanger Manufacturers Association, Tarrytown, New York.

\section{A.2 GOVERNMENT DOCUMENTS}

10 CFR 830.120, "Quality Assurance Requirements," Code of Federal Regulations, as amended.

10 CFR 835, "Occupational Radiation Protection," Code of Federal Regulations, as amended.

29 CFR 1910.120, "Occupational Safety and Health Standards," Code of Federal Regulations, as amended.

DOE-STD-1020-94, 1994, Natural Phenomena Hazards Design and Evaluation Criteria for Department of Energy Facilities, DOE Standard 1020-94, U.S. Department of Energy, Washington, D.C.

DOE-STD-3009-94, 1994, Preparation Guide for U.S. Department of Energy Nonreactor Nuclear Facility Safety Analysis Reports, U.S. Department of Energy, Washington, D.C.

Ecology, 1994, Hanford Federal Facility Agreement and Consent Order, as amended, Washington State Department of Ecology, U.S. Environmental Protection Agency, and U.S. Department of Energy, Olympia, Washington.

G-10 CFR 835/B2-Rev.0, Implementation Guide for Use with Title 10, Code of Federal Regulations, Part 835 Occupational Radiation Protection.

\section{A.3 SNF PROJECT DOCUMENTS}

HNF-2356, 1999, Spent Nuclear Fuel Project Cold Vacuum Drying Facility Operations Manual, Rev. 1, DE\&S Hanford, Inc., Richland, Washington.

HNF-3553, Spent Nuclear Fuel Project Final Safety Analysis Report, Annex B, "Cold Vacuum Drying Facility Final Safety Analysis Report", DRAFT, DE\&S Hanford, Incorporated, Richland, Washington. 
HNF-SD-SNF-DR-003, 1998, Multi-Canister Overpack Design Report, Rev. 3, Fluor Daniel Hanford, Inc., Richland, Washington.

HNF-SD-SNF-DRD-002, 1999, Cold Vacuum Drying Facility Design Requirements, Rev. 4, Fluor Daniel Hanford, Inc., Richland, Washington.

HNF-SD-SNF-SEL-002, 1999, Spent Nuclear Fuel Project Cold Vacuum Drying Facility Safety Equipment List, Rev. 6A, Fluor Daniel Hanford, Inc., Richland, Washington.

HSRCM-1, 1995, Hanford Site Radiological Control Manual, Rev. 2, Westinghouse Hanford Company, Richland Washington.

SNF-3001, 1999, Cold Vacuum Drying Facility Data and Calculation Database, Rev. 0, DE\&S Hanford, Inc., Richland, Washington.

SNF-3089, 1999, Cold Vacuum Drying Facility Security System Design Description, Draft, DE\&S Hanford, Inc., Richland, Washington.

SNF-4148, 1999, Spent Nuclear Fuel Project Cold Vacuum Drying Facility Master Equipment List, Rev. 0A, Fluor Daniel Hanford, Inc., Richland, Washington.

SNF-AP-5-006, ALARA Goals, Training, and Control Level Administration, DE\&S Hanford, Inc., Richland, Washington.

SNF-AP-5-012, Radiological ALARA Work Planning Process, DE\&S Hanford, Incorporated, Richland, Washington.

SNF-AP-5-013, Radiological ALARA Process, DE\&S Hanford, Inc., Richland, Washington.

W-441-P003, The Fabrication and Procurement Specification for the Monitoring and Control System, Fluor Daniel Hanford, Inc., Richland, Washington. 
SNF-3078 Rev 0

\section{Appendix B}

\section{System Drawings}

B-1 
Complete sets of drawings are located with the SNF Project files for the CVD Facility project.

\begin{tabular}{|c|l|c|}
\hline $\begin{array}{c}\text { Drawing } \\
\text { Number }\end{array}$ & \multicolumn{1}{|c|}{ Title } & \multicolumn{1}{|c|}{$\begin{array}{c}\text { Sheet } \\
\text { Number }\end{array}$} \\
\hline H-1-82160 & CVD Facility P\&ID Legend & 1 \\
\hline H-1-82161 & $\begin{array}{l}\text { CVD Facility Process Equipment Skid P\&ID MCO/Cask } \\
\text { Interface }\end{array}$ & 1 \\
\hline H-1-82163 & $\begin{array}{l}\text { CVD Facility Process Equipment Skid P\&ID MCO/Temp Water } \\
\text { System }\end{array}$ & 1 \\
\hline H-1-82164 & CVD Facility PWC P\&ID & 1 \\
\hline H-1-82165 & CVD Facility Safety-class Helium System P\&ID & 1 \\
\hline H-1-82222 & $\begin{array}{l}\text { CVD Facility Mechanical Utilities Compressed \& Instrument Air } \\
\text { P\&ID }\end{array}$ & 1 \\
\hline H-1-82223 & CVD Facility Mechanical Utilities Drainage System P\&ID & 1 \\
\hline
\end{tabular}


SNF-3078 Rev 0

Appendix C

System Procedures

C-1 
SNF-3078 Rev 0

System procedures for the de-ionized water system will be developed in the future. 
DISTRIBUTION SHEET

\begin{tabular}{|c|c|c|c|c|c|}
\hline \multirow{2}{*}{$\begin{array}{l}\text { To } \\
\text { Distribution }\end{array}$} & \multirow{2}{*}{\multicolumn{3}{|c|}{$\begin{array}{l}\text { From } \\
\text { Technical Integration }\end{array}$}} & \multicolumn{2}{|l|}{ Page 1 of 1} \\
\hline & & & & \multicolumn{2}{|c|}{ Date June 14,1999} \\
\hline \multirow{2}{*}{\multicolumn{4}{|c|}{$\begin{array}{l}\text { Project Title/Work Order } \\
\text { SNF-3061, SNF-3066, SNF-3067, SNF-3072, SNF-3073, SNF=3074, } \\
\text { SNF-3077, SNF-3078, SNF-3079, SNF-3080, SNF-3081 }\end{array}$}} & \multirow{2}{*}{\multicolumn{2}{|c|}{$\begin{array}{l}\text { EDT No. } 626308,62631 \\
\text { ECN No. NA }\end{array}$}} \\
\hline & & & & & \\
\hline Name & MSIN & $\begin{array}{l}\text { Text } \\
\text { With All } \\
\text { Attach. }\end{array}$ & Text Only & $\begin{array}{l}\text { Attach./ } \\
\text { Appendix } \\
\text { Only }\end{array}$ & $\begin{array}{c}\text { EDT/ECN } \\
\text { Only }\end{array}$ \\
\hline W. C. Alaconis & R3-86 & $\mathrm{X}$ & & & \\
\hline L. L. Blehm & X3-86 & $\mathrm{X}$ & & & \\
\hline K. A. Boes & R3-86 & $X$ & & & \\
\hline J. R. Brehm & R3-86 & $\mathrm{X}$ & & & \\
\hline C. S. Haller & R3-11 & $\mathrm{X}$ & & & \\
\hline L. C. McKenzie & $\mathrm{S} 2-45$ & $\mathrm{X}$ & & & \\
\hline S. L. Mischke & R3-86 & $\mathrm{X}$ & & & \\
\hline C. C. Pitkoff & R3-86 & $\mathrm{X}$ & & & \\
\hline CVD Project File & $\mathrm{R} 3-86$ & $\mathrm{X}$ & & & \\
\hline SNF Project File & R3-11 & $\mathrm{X}$ & & & \\
\hline
\end{tabular}

